\title{
Silicon Nanohole Arrays Fabricated by Electron Beam Lithography and Reactive Ion Etching
}

(Fabrikasi Lubang Nano Silikon Oleh Litografi Alur Elektron dan Punaran Ion Reaktif)

\author{
Lita Rahmasari, Mohd Faizol AbDullah, Ahmad RifQi Md Zain \& AbDUl Manaf Hashim*
}

\begin{abstract}
The fabrication of silicon nanohole (SiNH) using a combination of electron beam lithography (EBL) and reactive ion etching (RIE) processes is reported. The optimum exposure dose of EBL process was found to be in the range of 210 $240 \mu \mathrm{C} / \mathrm{cm}^{2}$ due to small enlargement of hole diameter after pattern development process. The anisotropic etching and isotropic etching was achieved at low and high reaction pressures, respectively. As expected, the etching rate increase with time and RF power. A relatively smooth and well-defined NH has been obtained at RF power of $100 \mathrm{~W}$ and reaction pressure of 0.08 Torr, which is suitable to be applied for optical waveguide.
\end{abstract}

Keywords: Electron beam lithography; reactive ion etching; silicon nanohole

\section{ABSTRAK}

Fabrikasi lubang nano silikon (SiNH) menggunakan gabungan proses litografi alur elektron (EBL) dan punaran ion reaktif (RIE) dilaporkan. Dos pendedahan proses EBL yang optimum telah dijumpai dalam julat $210-240 \mu \mathrm{C} / \mathrm{cm}^{2} \mathrm{kerana}$ pembesaran diameter lubang yang kecil selepas proses pembangunan corak. Punaran anisotropik dan punaran isotropik masing-masing telah diperoleh pada tekanan reaksi yang rendah dan yang tinggi. Seperti yang dijangkakan, kadar punaran meningkat dengan masa dan kuasa RF. NH yang secara relatifnya licin dan bagus takrifannya telah diperoleh pada kuasa $R F 100 \mathrm{~W}$ dan tekanan reaksi 0.08 Torr, sesuai untuk diaplikasi untuk pandu gelombang optik.

Kata kunci: Litografi alur elektron; lubang nano silikon; punaran ion reaktif

\section{INTRODUCTION}

Recently, silicon ( $\mathrm{Si}$ ) has been studied as a core material for the photonic application such as a photonic waveguide where the fabrication of nanohole $(\mathrm{NH})$ arrays become necessary (Zou et al. 2018). Such nanostructure can alter the property of Si for the effective interaction with photon (Zou et al. 2018). There are several techniques available to fabricate $\mathrm{SiNH}$ arrays which can be categorized into two categories, namely direct milling such as focused ion beam (FIB) (Escobedo 2013) and lithography (Awad et al. 2004). There are several types of lithography such as colloidal lithography (Cong et al. 2009), laser holographic lithography (Meng et al. 2012), and electron beam lithography (EBL) (Abd Rahman et al. 2013) where these lithography processes need to be combined either with the wet chemical etching (Tiron \& Mollard 2007) or the dry etching such as reactive ion etching (RIE) (Awad et al. 2004; Mat Hussin et al. 2017) in producing NH.

Among these lithography techniques, EBL is considered as a promising technique in producing uniform and well-aligned $\mathrm{NH}$ arrays due to its high resolution and precise direct writing (Escobedo 2013). Since this technique involves the irradiation by the accelerated electron beam, the exposure condition of EBL beam on the coated resist need to be well established and controlled. On the other hand, RIE is considered as a promising technique compared to wet etching due to its excellent capability to realize anisotropic etching in producing $\mathrm{NH}$ with smooth and sharp side wall. Since this RIE process involves the use of etching gasses, several parameters such as a mixing ratio of gasses or flow rate, $\mathrm{RF}$ power, etching pressure need to be optimized. In this work, we investigate the effect of exposure dose of electron beam for the EBL process and the effect of etching pressure and RF power for the RIE process in fabricating SiNH arrays.

\section{EXPERIMENTAL DETAILS}

The schematic of SiNH arrays is shown in Figure 1. Here, NHs are arranged in triangular array where the hole diameter $\left(\mathrm{D}_{0}\right)$ is $250 \mathrm{~nm}$ and the pitch $(\mathrm{P})$ is $500 \mathrm{~nm}$. The depth (T) is defined by the etching time. Figure 2(a)-2(f) summarizes the overall steps of SiNH fabrication. Singlepolished n-type Si (100) wafer (725 $\mu \mathrm{m}$-thick, resistivity of $0.8-1.2 \Omega \mathrm{cm})$ is cleaved into $1 \times 1 \mathrm{~cm}^{2}$. The sample is subjected to ultrasonic-assisted organic cleaning using acetone for $5 \mathrm{~min}$, rinsed with isopropanol, followed by native oxide removal in $10 \%$ hydrofluoric (HF) acid for $30 \mathrm{~s}$. Finally, the sample is rinsed in de-ionized water and blow dried using nitrogen $\left(\mathrm{N}_{2}\right)$. Prior to resist coating, Si surface is treated with hexamethyldisilane (HMDS) to promote adhesion. The sample is then spin-coated with 


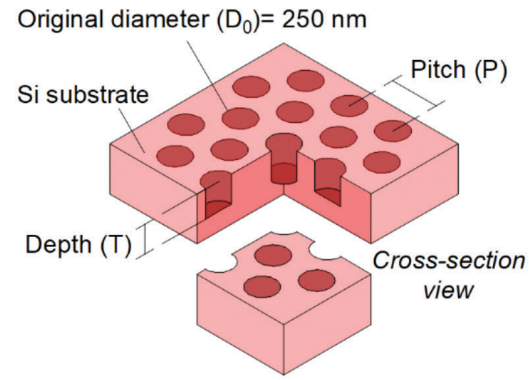

FIGURE 1. Schematic of SiNH in a triangular array

(a)

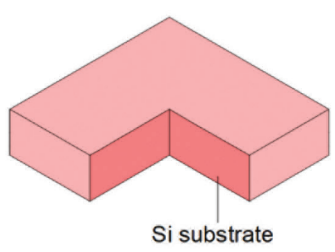

(d)

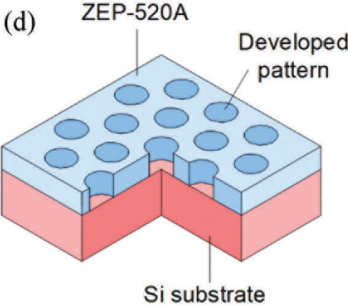

(b)

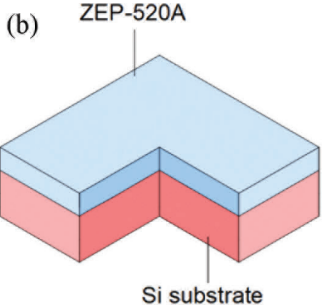

(e)

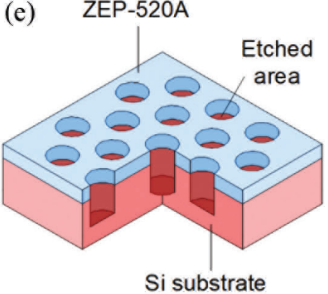

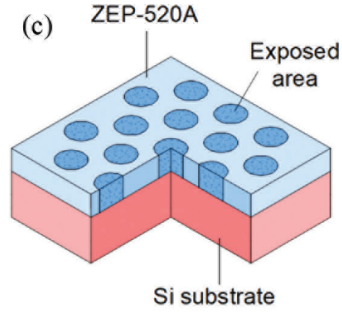

(f)

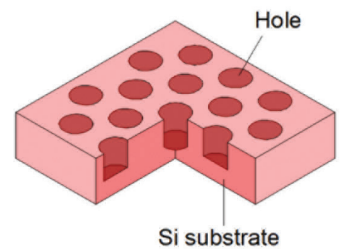

FIGURE 2. Schematic of fabrication processes (a) cleaning of Si (b) spin-coating of Si with ZEP-520A (c) patterning process using EBL (d) development of hole pattern (e) RIE etching of holes and (f) removal of ZEP-520A residue

undiluted ZEP-520A (positive electron beam resist) at $500 \mathrm{rpm}, 1,500 \mathrm{rpm}$ and 3,000 rpm for $5 \mathrm{~s}, 15 \mathrm{~s}$ and $40 \mathrm{~s}$, respectively. The sample is pre-baked in the oven at $90^{\circ} \mathrm{C}$ for $5 \mathrm{~min}$, followed by another baking at $180^{\circ} \mathrm{C}$ on hot plate for $2 \mathrm{~min}$. By using this recipe, homogenous resist coating with thickness around $400 \mathrm{~nm}$ is obtained.

The direct electron beam writing is carried out using an EBL system (JEOL JBX-6300FS) at constant acceleration voltage of $100 \mathrm{kV}$ and constant emission current of $1 \mathrm{nA}$. The exposure dose is varied in the range of $210-280 \mu \mathrm{C} /$ $\mathrm{cm}^{2}$. After the exposure, the pattern is developed in xylene for $60 \mathrm{~s}$, rinsed in isopropanol for $30 \mathrm{~s}$, and finally blow dried using $\mathrm{N}_{2}$. The dry etching process is carried out using a RIE system (NSC ES401) at constant temperature of $30^{\circ} \mathrm{C}$ and constant sulfur hexafluoride $\left(\mathrm{SF}_{6}\right)$ flow rate of $30 \mathrm{sccm}$. The pressures are set at 0.08 Torr and 0.20 Torr, while the RF powers are set at $100 \mathrm{~W}, 200 \mathrm{~W}$ and $300 \mathrm{~W}$. The etching times are also varied in the range of 30-150 s. After etching, the residue of ZEP-520A resist on sample is removed using methyl ethyl ketone, followed by an ultrasonic organic cleaning. The surface morphology of SiNH is evaluated using field-effect scanning electron microscopy (FESEM) (JEOL JSM-7800F). While, the crosssection of SiNH is fabricated using FIB and inspected using FESEM (FEI Helios NanoLab G3 UC).

\section{RESULTS AND DISCUSSION}

Figure 3 shows the dependency of the hole diameter after development $\left(\mathrm{D}_{\text {dev }}\right)$ in respect to the exposure dose. There are three different changes of the hole diameters. The exposure dose ranged from $210-240 \mu \mathrm{C} / \mathrm{cm}^{2}$ produces less enlargement of hole diameters about $+13.6 \%$ from the original patterned hole diameter $\left(\mathrm{D}_{0}\right)$. The enlargement increases to $+14.4 \%$ and $+16.4 \%$ for dose of $250-270$ $\mu \mathrm{C} / \mathrm{cm}^{2}$ and $280 \mu \mathrm{C} / \mathrm{cm}^{2}$, respectively. It is well reported that a close packed arrangement of holes may generate a so-called 'proximity effect', where unintentional exposure due to the scattering of electron beam will take place. A critical dimension (CD) is defined as a distance between the center of individual hole and its neighboring hole. As an example, for the design with dimensions, $\mathrm{D}_{0}=250 \mathrm{~nm}$ and $\mathrm{P}=500 \mathrm{~nm}$, the $\mathrm{CD}$ will be $250 \mathrm{~nm}$. Considering $+13.6 \%$ enlargement of the hole diameter after the development process, the distance between the two holes is now reduced to $216 \mathrm{~nm}$. Hence, the reduction percentage of $\mathrm{CD}$ is determined to be $13.6 \%$ which is equal to the enlargement percentage of the hole diameter. This reduction percentage of $\mathrm{CD}$ is relatively large and further improvement can be possibly made by intensive study on various affecting factors such as resist viscosity, current, 


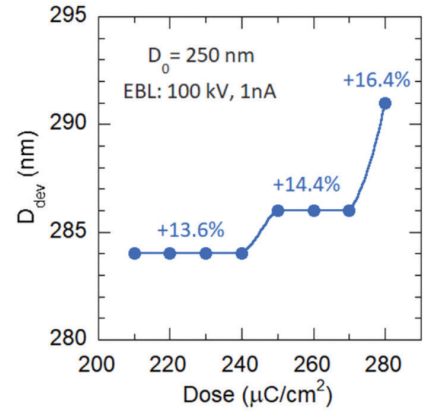

FIGURE 3. Dependency of hole diameters after being developed on the dose. Inset percentage shows the enlargement percentage from the original designed hole diameters

developing chemicals, and electron beam alignment (Seo et al. 2000). We believe that for the large pitch of hole arrays as used in this study, such reduction percentage is considered acceptable.

Figure 4(a) shows the FESEM image (top view) of developed ZEP-530A hole pattern on Si after being exposed with dose of $230 \mu \mathrm{C} / \mathrm{cm}^{2}$. The $\mathrm{D}_{\text {dev }}$ is estimated to be around $284 \mathrm{~nm}$ (corresponds to $+13.6 \%$ enlargement). Figure 4(b) shows the top view of the hole structures after being subjected to $30 \mathrm{~s}$ etching at pressure of 0.20 Torr. It is estimated that the diameter of holes after etching $\left(\mathrm{D}_{\text {etch }}\right)$ for $30 \mathrm{~s}$ is approximately $307 \mathrm{~nm}$ (corresponds to $+22.8 \%$ enlargement). Prolonging the etching time up to $60 \mathrm{~s}$, the hole shape has been eliminated due to aggressive or over etching as shown in Figure 4(c). Such high reaction pressure of 0.20 Torr seems to result to the isotropic etching of $\mathrm{Si}$. It is well reported that the amount or quantity of etching species generated from the dissociation of $\mathrm{SF}_{6}$ gas, i.e. $\mathrm{SF}_{x}^{+}$ions, $\mathrm{F}^{*}$ radicals and F-ions, increase with the pressure (Jensen et al. 1996). Thus, this situation will enable those species to react and perform isotropic etching on the Si substrate in both downward and lateral direction. As a result, $\mathrm{D}_{\text {etch }}$ is directly enlarged by prolonging the duration of isotropic etching. After $60 \mathrm{~s}$ as shown in Figure 4(c), it can be seen that all individual holes become in contact to each other. Since the lateral etching is less promoted or weak compared to the downward etching, the side wall etching is controlled or promoted according to the Si planes.
Due to this situation, the holes with hexagonal shape are formed.

The anisotropic etching is found to be well promoted at low reaction pressure of 0.08 Torr. When the pressure is lowered to 0.08 Torr, the chamber is now less occupied by those etching species. As a result, these etching species are directed to the exposed Si surface in downward direction to promote the anisotropic etching. Figure 5 shows the dependency of etching depth in respect to the etching time for both types etching, isotropic ( 0.20 Torr) and anisotropic (0.08 Torr). As expected, a linear dependency is observed for both types of etching where the depth increases with the etching time. The isotropic etching rate for $\mathrm{Si}$ at 0.20 Torr is calculated to be $462 \mathrm{~nm} / \mathrm{min}$, while the anisotropic etching rate at 0.08 Torr is $276 \mathrm{~nm} / \mathrm{min}$. The anisotropic etching rate is slower than isotropic etching rate due to the decrease of etching species for etching.

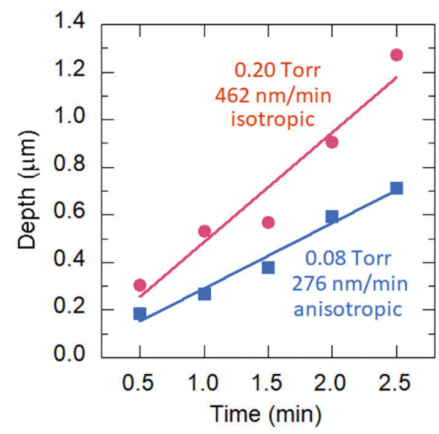

FIGURE 5. Co-relation of etching depth and etching time as a function of chamber pressure

Figure 6(a)-6(c) shows the FESEM images of fabricated SiNH after being etched at RF power of 100, 200 and 300 $\mathrm{W}$, respectively. Cross-sectional view of $\mathrm{SiNH}$ is obtained by precise cutting using FIB at the center of hole diameter. The $\mathrm{D}_{\text {etch }}$ values of SiNH are estimated to be around 320 $\mathrm{nm}(100 \mathrm{~W}), 300 \mathrm{~nm}(200 \mathrm{~W})$ and $400 \mathrm{~nm}(300 \mathrm{~W})$, thus generating etching rate of $160 \mathrm{~nm} / \mathrm{min}, 150 \mathrm{~nm} / \mathrm{min}$ and $200 \mathrm{~nm} / \mathrm{min}$, respectively. It is worth to note that the diameters of SiNH after being etched at those three RF powers show almost same dimension around $370 \mathrm{~nm}$ corresponds to about $+48.0 \%$ enlargement from the original
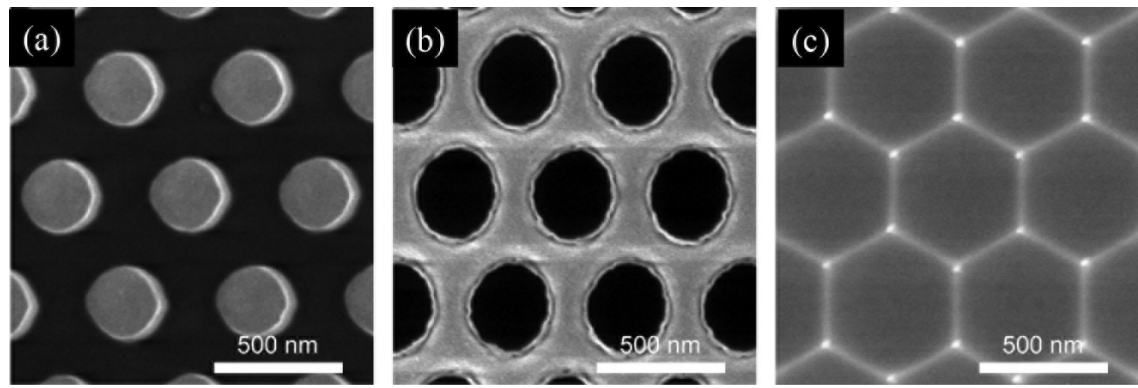

FIGURE 4. Top view FESEM images (a) after development (b) after etching for $30 \mathrm{~s}$ and (c) after etching for $60 \mathrm{~s}$. Chamber pressure $=0.20$ Torr and $\mathrm{RF}$ power $=300 \mathrm{~W}$ 

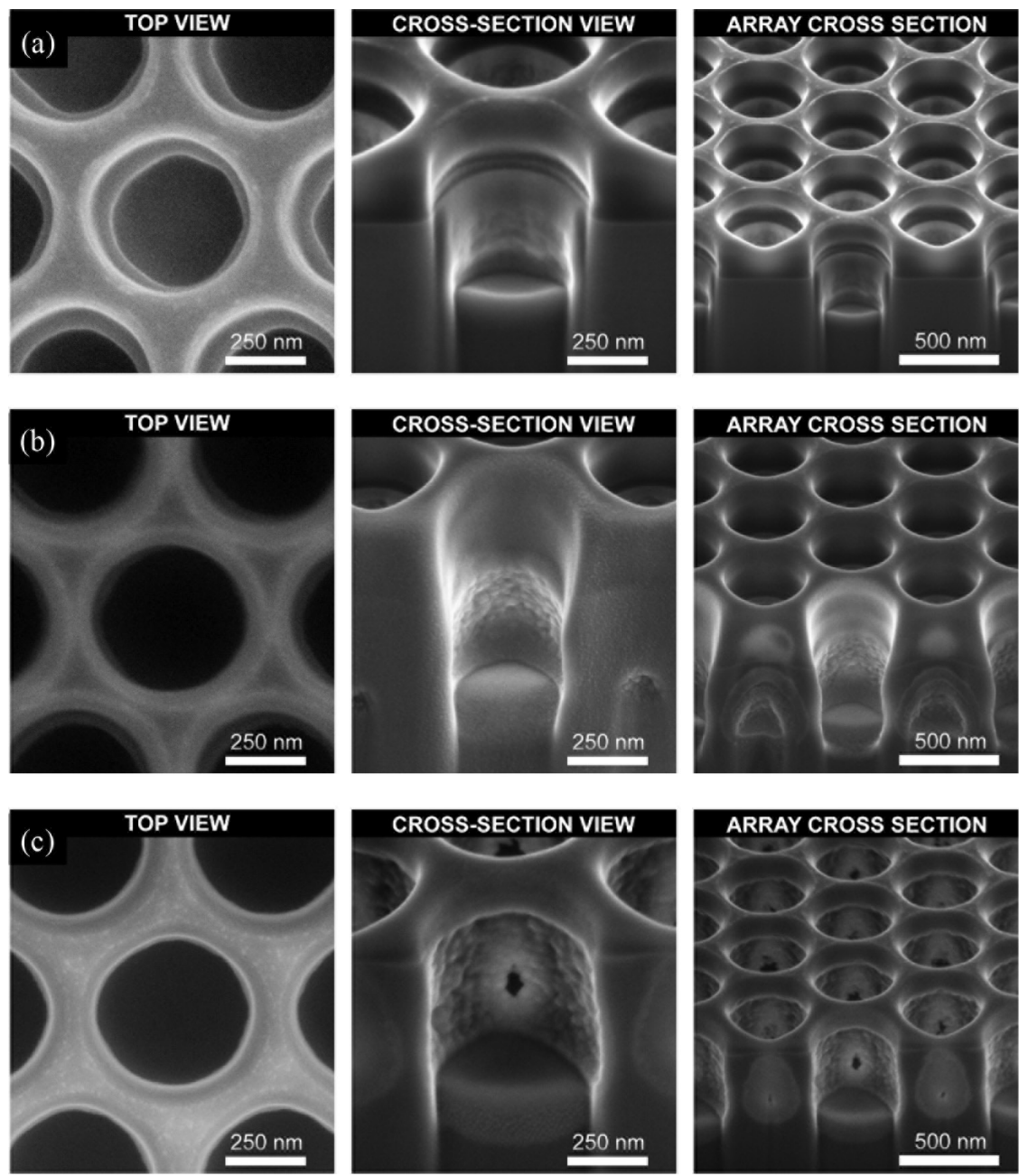

FIGURE 6. FESEM images of the SiNH after etching at RF power of (a) $100 \mathrm{~W}$ (b) $200 \mathrm{~W}$ and (c) $300 \mathrm{~W}$.

Etching time $=2 \mathrm{~min}$, etching pressure $=0.08$ Torr

designed hole diameter, i.e. $250 \mathrm{~nm}$. The etching rate of SiNH is almost same at 100 and $200 \mathrm{~W}$ of RF power, but it drastically increased at RF power of $300 \mathrm{~W}$. RF power is used to drive reaction in the chamber; when RF power increased the plasma gas attack not only vertically but also horizontally of the holes. The aspect ratio (AR) of $\mathrm{SiNH}$ and the etching selectivity are tabulated in Table 1. Here, AR and etching selectivity are calculated using (1) and (2), respectively. It can be seen that both AR and selectivity increase with the RF power.

$$
\mathrm{AR}=\mathrm{NH} \text { depth } / \mathrm{NH} \text { diameter }
$$

$$
\begin{aligned}
\text { Etching selectivity }= & \text { Etching rate of ZEP-520A/ } \\
& \text { Etching rate of } \mathrm{Si}
\end{aligned}
$$

It can be seen that the sidewall of $\mathrm{SiNH}$ side wall etched at RF power of $100 \mathrm{~W}$ shows relatively smooth and flat surface. By increasing the RF power, plasma density in reaction chamber is increased. Higher plasma density enhances the dissociation of $\mathrm{SF}_{6}$ to create the etching species and eventually will increase the etching rate. Jiao et al. (2015) in their work concluded that at low RF power, the contribution of physical sputter etching is low since plasma density and ion energy in the chamber is low. Here, they obtained good verticality of etched InP waveguide by using $100 \mathrm{~W}$ of $\mathrm{RF}$ power and $\mathrm{CH}_{4} / \mathrm{H}_{2}$ gasses. In this work, high etching rate after increasing RF power to $300 \mathrm{~W}$ also contributes to aggressive horizontal etching as shown in Figure 6(c). Aggressive etching results to rough sidewall and creates through hole with the neighboring NH. Since

TABLE 1. AR and selectivity of SiNH

\begin{tabular}{ccc}
\hline RF power & AR & Selectivity \\
\hline $100 \mathrm{~W}$ & 0.865 & 0.725 \\
$200 \mathrm{~W}$ & 0.811 & 0.767 \\
$300 \mathrm{~W}$ & 1.081 & 0.790 \\
\hline
\end{tabular}


sidewall roughness and well-defined $\mathrm{NH}$ are very crucial in optical waveguide devices, it can be concluded that high RF power of $300 \mathrm{~W}$ is not suitable to be applied in the fabrication of SiNH.

\section{CONCLUSION}

In this article, the fabrication of SiNH using a combination of EBL and RIE processes was demonstrated. The optimum exposure dose of EBL process was found to be in the range of $210-240 \mu \mathrm{C} / \mathrm{cm}^{2}$ due to small enlargement of hole diameter after development process. The anisotropic etching and isotropic etching was achieved at low and high reaction pressures, respectively. As expected, the etching rate increase with time and RF power. A relatively smooth and well-defined NH was obtained at RF power of $100 \mathrm{~W}$ and reaction pressure of 0.08 Torr.

\section{ACKNOWLEDGEMENTS}

Lita Rahmasari thanks the Japan ASEAN Integrated Fund for the scholarship. This work is funded by Universiti Teknologi Malaysia and the Ministry of Education (Malaysia) through various research grants.

\section{REFERENCES}

Abd Rahman, S.F., Kasai, S. \& Hashim, A.M. 2013. Fabrication and transport performance characterization of chemicallydoped three-branch junction graphene device. Sains Malaysiana 42(2): 187-192.

Awad, Y., Lavalle, E., Lau, K.M., Beauvais, J., Drouin, D., Turcotte, D., Yang, P. \& Kelkar, P. 2004. Array of holes fabricated by electron-beam lithograpy combined with image reversal process using nickel pulse reversal plating. ऐ. Vac. Sci. Technol A. 22(3): 1040-1043.

Cong, C., Junus, W., Shen, Z. \& Yu, T. 2009. New colloidal lithographic nanopatterns fabricated by combining preheating and reactive ion etching. Nanoscale Res. Lett. 4(11): 1324-1328.

Escobedo, C. 2013. On-chip nanohole array based sensing: A review. Lab Chip 13(13): 2445-2463.

Jensen, H., Gardeniers, H., De Boer, M., Elwenspoek, M. \& Fluitman, J. 1996. A survey on the reactive ion etching of silicon in microtechnology. J. Micromechanics Microengineering 6(1): 14-28.

Jiao, Y., de Vries, T., Unger., R.S., Ambrosius, H., Radu, C., Arens, M., Smit, M. \& van der Tol, J. 2015. Vertical and smooth single-step reactive ion etching process for InP membrane waveguides. J. Electrochem. Soc. 162(8): E90-E95.
Mat Hussin, M.R., Ramli, M.M., Wan Sabli, S.K., Md Nasir, I., Syono, M.I., Wong, H.Y. \& Zaman, M. 2017. Fabrication and characterization of graphene-on-silicon Schottky diode for advanced power electronic design. Sains Malaysiana 46(7): 1147-1154.

Meng, X., Depauw, V. \& Gomard, G. 2014. Micrometer-thin crystalline-silicon solar cells integrating numerically optimized 2-D photonic crystals. IEEE J. Photovolt. 20(4): 215-223.

Seo, E., Choi, B.K. \& Kim, O. 2000. Determination of proximity effect parameters and the shape bias parameter in electron beam lithography. Microelectron Eng. 53: 305-308.

Tiron, R. \& Mollard, L. 2007. Ultrahigh-resolution pattern using electron beam lithography HF wet etching. J. Vac. Sci. Technol. B 4(25): 1147-1151.

Zou, Y., Chakravarty, S., Chung, C.J., Xu, X. \& Chen, R.T. 2018. Mid-infrared silicon waveguides and devices. Photon. Res. 4(6): 254-276.

Lita Rahmasari, Mohd Faizol Abdullah \& Abdul Manaf Hashim* Malaysia-Japan International Institute of Technology

Universiti Teknologi Malaysia

Jalan Sultan Yahya Petra

54100 Kuala Lumpur, Federal Territory

Malaysia

Lita Rahmasari

Faculty of Teacher Training and Education

Sebelas Maret University, Surakarta

Indonesia

Ahmad Rifqi Md Zain

Institute of Microengineering and Nanoelectronics

Universiti Kebangsaan Malaysia

46300 UKM Bangi, Selangor Darul Ehsan

Malaysia

Ahmad Rifqi Md Zain

Harvard John A Paulson

School of Engineering and Applied Science

Harvard University, Cambridge, MA

United States of America

*Corresponding author; email: abdmanaf@utm.my

Received: 16 July 2018

Accepted: 15 November 2018 